\title{
Influence of Integrated Teaching Strategies on Quality of Student Outcomes in A Clinical Nutrition Course in Undergraduate Level at Nutrition Department Faculty of Public Health; University of Benghazi
}

\author{
Faiza Nouh*, Salima Elfagi, Mariam Omar
}

Nutrition Department, Faculty of Public Health University of Benghazi

DOI: $10.36348 /$ jaep.2020.v04i04.005

| Received: 04.04 .2020 | Accepted: 11.04.2020 | Published: 22.04.2020

*Corresponding author: Faiza Nouh

Abstract

Teaching of health sciences courses is one of the most significant steps to develop the higher education sector. Integrated versus traditional teaching has been the area of discussion in many publications. In this paper, the authors will try to assess the influence of integrated teaching strategies on student outcomes in a clinical nutrition course in undergraduate level at Nutrition Department Faculty of Public Health; University of Benghazi. The exams results assessment showed that, exam scores for the blended teaching approach were statistically significantly higher than for the traditional teaching approach for both mid-year assessments and final exams.

Key words: Integrated, Teaching, Nutrition.

Copyright @ 2020: This is an open-access article distributed under the terms of the Creative Commons Attribution license which permits unrestricted use, distribution, and reproduction in any medium for non-commercial use (NonCommercial, or CC-BY-NC) provided the original author and sources are credited.

\section{INTRODUCTION}

Over the past twenty years, there have been an developing in the number of courses in the health sciences, as well as courses across faculties and universities, have incorporated active learning, self learning, problem solving and online course components. Of particular interest are programs that include integrated teaching designs, where some course elements are presented in a traditional classroom setting while other course elements are delivered by different clinical filed visits, students case study based learning, and case scenario presentation [1]. Integrated teaching designs involves a combination of learning components, with the center being that the elements work together as a single integrated course $[2,3]$.

Even though the reasons for providing integrated teaching experiences may vary across faculties and universities, from a learning perspective a critical question is whether such designs are effective and, given the shift from more strongly classroombased teaching approach, whether integrated teaching approaches differ in terms of the students learning outcomes and achievements as a result of the course. Moreover, it is also important to assess how students experience the integrated teaching experiences and their feedback on its effectiveness $[4,5]$.
While there is a relatively large body literature on effectiveness of fully self learning approach, online course delivery, fewer papers have assessed the integrated teaching approach. This is particularly true for undergraduate health sciences programs, as much of the literature has focused on graduate education [6] .Different teaching strategies are logically suited to make balancing between a "match" between learning task and delivery method [3]. Further, arguments have been made that "freeing up" students during class time by moving from lecture to case presentation, problem solving, group discussion, allowing for greater engagement in active learning [4]. Many others studies have found no differences in outcomes across the passive and active of teaching methods. Some publications have argued that the efficacy of different teaching strategies may depend on the goals of learning outcomes, with active and passive teaching methods being equivalent for low students' skills [7]. There has been limited research conducted on the problems facing Libya higher education. There are almost $70 \%$ of male and $35 \%$ of female were literate in the early 1980 's in Libya. This has increased in 2004 to make literacy for male more than $90 \%$, and more than $70 \%$ for female. The Libyan higher education system is very developed comparing to other in last 6 decades ago. However, any system growing rapidly faces mistakes and challenges. During the period between the 1980 up to 1999 , the Libyan higher education system faced many challenges, 
particularly in the use of different instructions system. The quality of higher education in Libya requires more attention. This has made the government come up with various intervention strategies. The education system in Libya so far has sought to provide a multiple options through which students can access curricula programs. This paper aims to assess the influence of integrated teaching strategies on student outcomes in a clinical nutrition course in undergraduate level at Nutrition Department Faculty of Public Health; University of Benghazi [8, 9].

\section{METHODOLOGY Subjects}

Subjects were 66 graduate students enrolled in course of clinical nutrition at Faculty of Public Health (38 students in the blended teaching model, 28 students in the "traditional" model). The traditional model was applied with those students who graduated before 2008; while the blended model was applied with those who graduated from 2008 up to now.

\section{STUDY DESIGN}

In a quasi-experimental, non-equivalent control group study, students' outcomes for a blended teaching approach were compared to those for a more traditional, lectures and classroom-based delivery.

\section{DATA COLLECTION \\ Course description}

The course is an undergraduate $s$ level covering the main aspects of the clinical nutrition sciences in public health. The course is a required core course for all students enrolled in the university's Bachelors' of Public Health Nutrition program. During the period before 2006, the course was taught in a relatively traditional format. Students completed out of class lecture each week (typically 2-4 hours per week). All course content was done in class through instructor lecturing. Approximately $100 \%$ of in class time was lecture-based. During the "blended teaching" era, all teaching approaches were used with student. Class time was then almost entirely (at least $50 \%$ of class time) devoted to active practical approaches. Lectures only took place to clarify points of student confusion or where integrating teaching approaches for the activity's successful implementation of cases study. The teaching objectives and the course contents remained the same during the two models. The key changes from baseline to blended, then, were: a) introduction of didactic cases presentation rather than basic knowledge lectures; and b) given the shift to manual sheets, freeing of in class time for more active, in depth learning interaction.

\section{Ethical Approval}

Informed consent was obtained from subjects who were also assured of the confidentiality of the information collected. The research was approved by the administration of the Faculty of Public Health, University of Benghazi.

\section{Evaluation components}

\section{Clinical nutritional manual book and exams}

The course was broken up into four units, nutrition assessment, analysis, interpretation, intervention and follow up. Following each unit, students completed a cumulative unit of clinical nutrition manual sheet. This approach was applied from 2006 up to today. Additional assessment methods include case presentation, case based problem solving, group discussion. Before 2006; the only assessment methods were mid-year assessment and final exam.

\section{Course Evaluation}

Subjects anonymously completed a standardized, wide course evaluation. The evaluation included closed-ended ratings of both the quality of the course and the quality of the instructor. For both of these ratings, subjects responded on a 5 points scale with endpoints of $1=$ unacceptable and $5=$ one of the best. Subjects then responded to two open-ended questions: "Please comment on elements of the course you found particularly effective" and "Please comment on course improvements you would suggest." In addition, a supplemental evaluation question was added in which subjects were asked "Given the option, would you prefer to take the course in the blended format or in a more "traditional" lecture in class format?"

\section{STATISTICAL ANALYSIS}

The key test for the relative efficacy of the blended teaching format is comparison of exam achievements and course point totals across the two approach blended and traditional methods. For solving the issue of the non-equivalent control group design, a primary threat to validity of this test is differences in subjects' characteristics across the two approaches. For that reason, prior to analyses the research examined equivalence of the students on prior academic performance (indexed by first two years in faculty; before enrolling in the study at Nutrition Department). There were no differences across the two approaches. The exam analyses were conducted using repeated measures ANOVA with the three exam scores as a repeated measures outcome variable. Final course point total was similarly modelled using univariable ANOVA with the final course point total as the continuous outcome variable and the above predictors and covariates modelled. Finally, to test student feedback on the blended teaching approach, open-ended course evaluation feedback from the blended teaching approach was analysed. Responses were coded into a series of feedback categories. Non-exclusive coding was used as student response could be belonging to more than one answer category. Scores of the two closed-ended evaluation items were compared across two teaching methods using linear regression. 


\section{RESULTS}

Firstly, characteristics of the subjects during the two teaching methods were compared. The GPA during the first two years in the Faculty of the Public Health for the students does not different among the two groups; traditional approach mean GPA 3.56 $(\mathrm{SD}=0.51)$, blended approach mean GPA 3.49 $(\mathrm{SD}=0.24)$. In addition to GPA, students in the two approaches did not differ in terms of gender composition. The exams results assessment showed that, exam scores for the blended teaching approach were statistically significantly higher than for the traditional teaching approach for both mid-year assessments and final exams as shown in table one.
There were no differences in numerical ratings of either the course or the instructor across the two teaching approaches; for both questions during the response from subjects as can be seen in the table 2.27 students (73\%) mentioned that the blended teaching approach as an effective strategies of the course. The open-ended questions responses are presented in table 3 . Furthermore, students were asked to provide their preference for the blended teaching approach comparing to traditional approach. The blended delivery was preferred by $83 \%$ of the subjects $(n=33)$, whereas only $10 \%(n=4)$ selected the traditional method. The remaining $8 \%(n=3)$ chose a combination of the two approaches.

Table-1: Exam scores and final course scores by two teaching approaches

\begin{tabular}{|l|l|l|l|}
\hline $\begin{array}{l}\text { Course score component } \\
\text { (total possible points) }\end{array}$ & $\begin{array}{l}\text { Traditional delivery } \\
\text { M (SD) }\end{array}$ & $\begin{array}{l}\text { Blended } \\
\text { learning M (SD) }\end{array}$ & $\begin{array}{l}\text { Effect size for semester } \\
\text { differenced }\end{array}$ \\
\hline Assessment 1 (10 points) & $6.8(1.35)$ & $7.07(0.69)$ & 0.35 \\
\hline Assessment 2 (10 points) & $7.07(0.99)$ & $7.4(0.89)$ & 0.51 \\
\hline Clinical Practice (10 points) & $8.02(0.96)$ & $9.17(0.53)$ & -0.29 \\
\hline Total course point (100 points) & $71.76(4.95)$ & $83.92(2.45)$ & 0.57 \\
\hline
\end{tabular}

Table-2: Subjects evaluations, comparison by teaching methods

\begin{tabular}{|l|l|l|}
\hline Course Evaluation & $\begin{array}{c}\text { Traditional } \\
\text { delivery } \\
(\mathbf{N}=\mathbf{2 8})\end{array}$ & $\begin{array}{c}\text { Blended } \\
\text { learning } \\
(\mathbf{N}=\mathbf{3 8})\end{array}$ \\
\hline Overall rating of the course & 3.8 & 3.9 \\
\hline $\begin{array}{l}\text { Overall rating of the } \\
\text { teaching effectiveness }\end{array}$ & 4.1 & 4.1 \\
\hline
\end{tabular}

Table-3: Subjects evaluations for blended learning

\begin{tabular}{|c|c|}
\hline Response category & $\begin{array}{c}\text { Percentage } \\
\text { of responses }\end{array}$ \\
\hline \multicolumn{2}{|l|}{ Effective course components } \\
\hline $\begin{array}{l}\text { More blended approaches including online } \\
\text { courses }\end{array}$ & $54 \%$ \\
\hline In class discussions and activities & $44 \%$ \\
\hline Online learning materials (reading questions) & $16 \%$ \\
\hline Weekly suggested books & $10 \%$ \\
\hline \multicolumn{2}{|l|}{ Suggested course improvements } \\
\hline Learning books at faculty library & $18 \%$ \\
\hline $\begin{array}{l}\text { Balance between class activity and lecture } \\
\text { time }\end{array}$ & $15 \%$ \\
\hline Group project & $15 \%$ \\
\hline
\end{tabular}

\section{DISCUSSION}

This assessment of the influence of using a traditional approach versus a blended to delivering course in a under graduate level public health clinical nutrition course indicated several aspects of effectiveness. First, subjects outcomes during the blended teaching approaches were higher than during the traditional teaching approach both exam performance and overall course performance. Second, subjects' responses regarding the blended teaching method was mostly positive. The negative response regarding blended teaching method was received predominantly on how the blended approach was implemented rather than negativity about the method per se. The subjects prefer the blended learning teaching method rather than traditional method. One justification for this effect might be that, there was more "time on task" - subjects spent more time with each course component than before, and the integration of active learning activities for in-class time allowed for structuring "higher order". Time on task is one of the best practices for university education. Another possible justification is that that several subjects mentioned that they preferred the case presentation and discussion rather than traditional lecture material because it allowed them to engage, involve and participate, and revisit after a class session if they wanted to clarify a muddy point. Thus, the blended teaching approach might also determine how students interact with lecture material. Blended learning provides a combination of delivery mechanisms, techniques, and student engagement methods $[10,11]$. 


\section{LIMITATIONS}

Although care were taken to address this potential threat to internal validity such as testing for equivalence on a gender, controlling for prior academic achievement, however; the study design was not truly experimental in that students were not randomly assigned, thus, to the blended versus traditional teaching approach. It is essential to acknowledge that other variables might cause for the difference in learning outcomes across different teaching approaches. The current research does not assess differences in instructional approach, instructor enthusiasm, or other factors might contribute to the differences in findings reported here.

\section{CONCLUSIONS}

Shifting teaching method from a traditional approach to a blended learning approach may lead to an increase in student learning as assessed by exam performance and overall course point totals. Well designed and implemented blended teaching approaches may have strong influence for improving student learning outcomes in health sciences courses.

\section{Competing interests}

Authors have declared that no competing interests exist.

\section{REFERENCES}

1. Kate, M. S., Kulkarni, U. J., Supe, A., \& Deshmukh, Y. A. (2010). Introducing integrated teaching in undergraduate medical curriculum. Int J Pharm Sci Res, 1(1), 18-22.

2. Joglekar, S., Bhuiyan, P. S., \& Kishore, S. (1994). Integrated teaching--our experience. Journal of postgraduate medicine, 40(4), 231.

3. Ellaway, R. H., Kneebone, R., Lachapelle, K., \& Topps, D. (2009). Practica continua: connecting and combining simulation modalities for integrated teaching, learning and assessment. Medical Teacher, 31(8), 725-731.

4. Drake, S. M. (1998). Creating Integrated Curriculum: Proven Ways To Increase Student Learning. Corwin Press, Inc., 2455 Teller Road, Thousand Oaks, CA 91320 (cloth: ISBN-0-80396716-0, \$59.95; paper: ISBN-0-8039-6717-9, $\$ 26.95)$.

5. Harden, R. M. (2000). The integration ladder: a tool for curriculum planning and evaluation. Medical education-oxford-, 34(7), 551557.

6. Geyer, W., \& Effelsberg, W. (1998). The digital lecture board-a teaching and learning tool for remote instruction in higher education. In EdMedia+ Innovate Learning (pp. 63-69). Association for the Advancement of Computing in Education (AACE).

7. Kate, M. S., Kulkarni, U. J., Supe, A., \& Deshmukh, Y. A. (2010). Introducing integrated teaching in undergraduate medical curriculum. Int J Pharm Sci Res, 1(1), 18-22.

8. Tamtam, A., Gallagher, F., Olabi, A. G., \& Naher, S. (2011). Higher education in Libya, system under stress. Procedia-Social and Behavioral Sciences, 29, 742-751.

9. Rhema, A., \& Miliszewska, I. (2012). The potential of e-learning in assisting post-crisis countries in rebuilding their higher education systems: the case of Libya. Issues in informing Science and information technology, 9, 149-160.

10. Dandannavar, V. S. (2010). Effect of integrated teaching versus conventional lecturing on MBBS phase I students. Recent research in science and technology, 2(11).

11. Yadav, P. P., Chaudhary, M., Patel, J., Shah, A., \& Kantharia, N. D. (2016). Effectiveness of integrated teaching module in pharmacology among medical undergraduates. International Journal of Applied and Basic Medical Research, 6(3), 215. 